\title{
Balancing Freedom of the Press and Reasonable Restrictions in Bangladesh: An Appraisal
}

\section{Emdadul Haque}

LLM, Rajshahi University; Assistant Professor, Department of Law \& Justice, Southeast University, Dhaka; Independent Researcher and Freelance Journalist based in Dhaka, Bangladesh

\begin{abstract}
This article explores the balancing of freedom of the press and reasonable restrictions in Bangladesh under existing national laws and relevant international policy instruments. Across the globe, there is unending debate as to indoctrination of free press and reasonable restrictions. Bangladesh is not an exception to the tussle between these two notions. The free but fair press enables public debates and creates essential checks on government powers. The question of reasonable restrictions on press appears at the forefront of discussion as the press is also engaging in serving self-interest or value loaded vested interests vilifying its objectivity, impartiality, and accuracy. Though, the press and other media outlets of the country are partly free, the ongoing restrictions imposed by statutory laws and self-censorship have plunged the media into a stagnated ditch. However, journalists and media activists are gradually striving to overcome the hurdles of restrictions foreseeing a silver lining. On one hand, the country is globally lauded for its exponential progress in terms of economic, social and international goals and has emerged as an Asian tiger. On the other hand, the country is struggling to uphold the spirit of the free press in nourishing a healthy democracy amid good governance that tolerates diverse, dissent, pluralist views and constructive criticism.
\end{abstract}

Keywords: press freedom, reasonable restrictions, legal instruments, implications, balancing, Bangladesh.

JEL Classification: L82, K4.

Cite as: Haque, E. (2019). Balancing Freedom of the Press and Reasonable Restrictions in Bangladesh: An Appraisal. Business Ethics and Leadership, 3(1), 80-100. http://doi.org/10.21272/bel.3(1).80-100.2019.

(C) The Author, 2019. This article is published with open access at Sumy State University.

\section{Introduction}

Freedom of the press is one of the innocuous forms of all freedoms and bulwarks of liberty. Press freedom is essential for the development and functioning of democracy (Islam, 1995). Without substantial press freedom, the existence of people's rights and privileges in all spheres of a society is unimaginable in the modern era. The free and independent press not only acts as an important antidote to check any malpractice or maladministration of a government but also as a watchdog that depicts social wrongs. Acknowledging the perennial contribution of the press in a democratic society, it is considered as the 'Fourth Estate' alongside the three branches of a government. Freedom of the press is a core right and a touchstone of all rights recognized by both national and international laws. Bad governance needs secrecy to survive, to indulge corruption and maladministration but good governance needs openness to thrive. It is said that the $19^{\text {th }}$ century was dominated by novels and the $20^{\text {th }}$ century was dominated by movies but the $21^{\text {st }}$ century is dominated by the digital media (Albarran, 2010).

Freedom of the press comprises the right to information, right to know, right to be heard, right to publish or impart information, ideas and views not only in newspapers but also in electronic media and online media. It is a freedom of communication and expression through various means including the print, electronic and online media without interference or restriction. It denotes the liberty of accessing information, publishing and sharing one's speech, ideas and other forms of expression in any media without any prejudice, influence, and intimidation of censorship. With the growth of professionalism in journalism, journalists do collect, interpret and test news making a bridge to the source, government, and audience (Herbert, 2000).

Apart from socio-political issues, the preservation, promotion, and protection of the freedom of the press and restrictions in Bangladesh depend on its 1972 Constitution and other statutory laws along with some international legal instruments relevant for the country. The Bangladesh Constitution, 1972 is inbuilt with the freedom of the press amid some reasonable restrictions. There are a few laws allowing press freedom in the country but more laws restrict such freedom. The country is also a party to numerous international policy instruments including the Universal Declaration of Human Rights (UDHR), 1948, the International Covenant 
on Civil and Political Rights (ICCPR), 1996 and the Child Rights Conventions (CRC), 1989 along with some others under which she is obliged to comply with the freedom of the press. This paper postulates the present status of the press freedom and its limitations in the name of reasonable restrictions in Bangladesh analyzing the relevant statutory laws and international legal instruments. It spotlights the balancing of press freedom and reasonable restrictions through a delicate balance, sense of proportionality and reasonability. It also focuses on the opportunities and challenges for free press along with some findings and recommendations for accelerating the freedom of the press in parity with reasonable restrictions shedding light on the socio-legal dynamics of the country.

\section{Methodology}

This research is based on qualitative approach entailing subjective assessment, analysis, and observations. Basically, it is grounded on both the primary and the secondary sources such as relevant national statutory laws, international conventions, case laws, books, journals articles, conference papers, newspapers articles and documents from webpages. In preparing the paper a comparative approach as to the best practices of free press and reasonable restrictions is sought and applied to a large extent after the thorough review of existing documents. As a part of the study, the qualitative approach is adopted because such analysis in a comprehensive way has not been done yet as to the existing status of free press and reasonable restrictions in the light of statutory and international legal instruments relating to Bangladesh.

\section{History of the Press Law, Press Freedom and Restrictions}

The history of press law in the world can be traced back to the mid- $15^{\text {th }}$ century with the use of the printing press to book production in Western Europe (Kelly, 2004). After the invention of the printing press by the German craftsman Johannes Gutenberg in 1445, the printing press started booming. Initially, media regulation began against all forms of anti-state or anti-religious expressions. During that time, press laws were only confined to licensing of books and newspapers along with other products of printing press. Prior to the invention of the printing press, the Church or State assumed the right to control all forms of freedom of expression (FOE) distasteful to religion or State. In 1473, French king Louis XI granted letters patent giving the right of printing and selling books and newspapers. With the expansion of the printing trade and industry, Pope Alexander VI, in 1501, issued a bull against unlicensed printing which introduced the principle of censorship to restrict the press. Between 1524 and 1548, the Imperial Diet (Parliamentary Assembly) in Germany drew up various stringent regulations against the press.

The doctrine of press freedom as practiced today is a product of classical liberal political philosophies that began to emerge in Western Europe during the $17^{\text {th }}$ century (Milton, 1990). The British enacted the Bill of Rights Act, 1689 to allow press freedom to a limited extent. However, Sweden is a pioneer country granting press freedom to access public records of the government under the Freedom of the Press Act, 1766. In the $18^{\text {th }}$ century, the American Declaration of Independence, 1776 and the French Declaration of Rights of Man and of the Citizen, 1789 galvanized the foundation of freedom of the press. The $1^{\text {st }}$ Amendment of the American Constitution 1789 endorsed five freedoms including the freedom of press and freedom of speech.

In the British colonized India, restrictions on press activity started by the British soon after the journey of publication of a newspaper in the last quarter of the $17^{\text {th }}$ century. After the independence from the British in 1947, there have been waves of press freedom and subsequent restrictions by various regimes under diverse political stripes (Ahmed, 1999). In the history of undivided India, William Bolt in 1776 showed his interest in publishing the first newspaper in the subcontinent and was therefore ultimately deported back to England by the East India Company. James Augustus Hicky in 1780 published The Bengal Gazette, the first newspaper in India. It was seized in 1781 because Hicky published a scandalous story about the then Governor General and his wife. In East Pakistan (Bangladesh), the first Bangla newspaper named The Rangapur Barttabaha was published in Rangpur in August, 1847. In 1856, The Dacca News as the $1^{\text {st }}$ weekly English newspaper was printed and published in Dhaka.

The history of press law along with press freedom in Bangladesh may be discussed in three phases. The first phase (1757-1947) covers the British colonial rule and the press laws and regulations for the press of the undivided India imposed by the then rulers. The second phase (1947-1971) started under the auspices of the Pakistan government. The third phase (1971- present) began after the independence of Bangladesh coupled with the inheritance of the British and Pakistani laws. In true sense, the FOE and freedom of the press can be suppressed by formal and informal censorship. Both the British and Pakistani rulers exploited both the options (Marx, 2001). 

ISSN (online) - 2520-6311; ISSN (print) - 2520-6761

Soon after the publication of The Bengal Gazette as the first newspaper in undivided India in 1780, the legal mechanism to control press freedom stated by the British rulers. The Regulation of Lord Wellesley in 1799 came with the effect of pre-censorship of newspapers in undivided India. In 1823, an Ordinance was promulgated requiring compulsory licensing for all newspapers and periodicals. The Press Act of 1835 came with a mandatory provision of declaration for publishing any newspaper. As per this law, the printer and publisher would be responsible for the material published in a newspaper. The Licensing Act of 1857 brought stringent measures for absolute controlling of press freedom prohibiting any newspaper or press without a license from the Government. The Government reserved the discretionary right to grant licenses or revoke them at any time and was also empowered to prohibit the publication or circulation of any newspaper, book or other printed matter and seize them.

The Penal Code, 1860 and the Press and the Registration of Books Act, 1867 empowered the British government in restricting freedom of the press. Under the Vernacular Press Act of 1878 and the Code of Criminal Procedure (CrPC) 1898, the provision of sedition was added and the provision of confiscation of newspapers was added to prevent subversive activities of Indians against the British government. Section 99A of the CrPC, 1898 empowered the government to forfeit and seize any newspaper publishing any seditious matter. Finally, the Official Secrets Act, 1923 imposed the final nail on the coffin of the press freedom prohibiting official secret as news item. The Contempt of the Court Act of 1926 was a severe blow to press freedom in the Indian Sub-continent.

During the Pakistan regime, the provision of the press freedom was attached in article 8 of its Constitution of 1956 (Pakistan got a Constitution that was enforced on 23 March in 1956 after nine years of independence) but in reality, it was a mere formality of insertion of such provision. The military ruler took the total control of the Press in Pakistan under the Press and Publication Ordinance of 1961. Two newspapers namely The Daily Ittefaq and The New Nation of East Pakistan were closed down by the military ruler for criticizing the government. After the emergence of Bangladesh as an independent nation on 16 December 1971, the Constitution of the People's Republic of Bangladesh was adopted on 4 November 1972 and enforced on 16 December 1972 with the provision of the freedom of thought, conscience and of speech with reasonable restrictions under article 39.

Subsequently, replacing the Ordinance of 1961, the Printing Press and Publication (Declaration and Registration) Act, 1973 came up with the procedure of the operation of newspapers, printing presses, printers and registration of books. The Act bars any publisher and printer from printing and publishing anything that affects interests of State and the government. Under the Press Council Act, 1974, a Press Council as a media watchdog was formed in 1979 for expediting the freedom of press and improvement of the quality of news. Notably, Section 12(1) of the Press Council Act says that the Council will have the authority to warn, admonish and censure a newspaper or news agency after investigation if they violate the ethics of journalism or carry news against the public taste, or if an editor or a journalist commits any professional misconduct.

After the $4^{\text {th }}$ amendment of Bangladesh Constitution on 25 January 1975 and the inculcation of one party political system known as Bangladesh Krishak Sramik Awami League (BAKSAL) burying the multi-party democracy, the newspapers industry had a huge setback. On 13 June 1975, the Newspaper (Annulment of Declaration) Ordinance, 1975 was promulgated and subsequently, the government on 16 June closed all newspapers except four. Press freedom was restored by President Ziaur Rahman to a considerable extent except for political issues but after the assassination of General Zia in 1981, the process leading to martial law was reinforced in March 1982 by General Ershad who restricted press to a wider scale. The military governments in Bangladesh are at the bottom of allowing press freedom than the elected governments (Khatun et al, 2017). The wave of democratization in 1990 heralded a resurgence of press freedom in Bangladesh. Immediately after the fall of Ershad, the interim government scrapped the controversial provision 16A of the Press and Publication Act, 1973. Under clause 11 (2) (b) of the Press Council Act 1974, a set of Code of Conduct was declared for the journalists in 1993. The Information and Communication Technology (ICT) Act, 2006 through its section 57 (as amended in 2013) created a huge reign of panic and embarrassment for the journalists. But the Right to Information (RTI) Act, 2009 is a big breakthrough in enhancing press freedom. The National Broadcast Policy, 2014 is designed to supervise and regulate the activities of television channels and radio stations. The Journalist Welfare Trust Act, 2014 is a sign of good omen for the journalists as it addresses their economic safety and security. The National Online Mass Media Policy, 2017 was enacted to control the online news portals entailing professional responsibility. It reminds all reporters to uncover information and serve the society with complete news, not with fake news (Itule and Anderson, 2007). The Press Institute of Bangladesh (PIB) Act, 2018 was passed for the professional training and development of journalists. Finally, the Digital 
Security Act (DSA), 2018 was the final blow to the press freedom as the law is equipped with some black provisions hindering the FOE and investigative journalism.

Under the auspices of the UN, the General Assembly on 14 December in 1946 adopted Resolution 59(1) calling for an international conference on the freedom of information. The resolution states:

Freedom of information is a fundamental human right and ... the touchstone of all the freedoms to which the United Nations is consecrated.

Two years later, the UN adopted the Universal Declaration of Human Rights (UDHR), 1948 expressing a sacred commitment for the FOE in all forms including the press. Article 19 of the UDHR provides:

"Everyone has the right to freedom of opinion and expression; this right includes freedom to hold opinions without interference and to seek, receive and impart information and ideas through any media and regardless of frontiers".

The International Covenant on Civil and Political Rights (ICCPR), 1966 guarantees the right to freedom of thought, conscience and religion under article 18 while the freedom of the press, opinion, and expression is protected under article 19 apart from the protection of the right to peaceful assembly under article 21 and the right to freedom of association under article 22. But article 19(3) of the ICCPR also provides three restrictions on the freedom of expression, subject to the provision of law, necessity as to privacy to respect of the rights of others and for the protection of national security or of public order or of public health or morals.

Moreover, articles 4 and 5 of the Convention on the Elimination of All Forms of Racial Discrimination (CERD), 1965; article 15(3) of the International Covenant on Economic, Social and Cultural Rights (ICESCR), 1966; articles 12 and 13 of the Convention on the Rights of the Child (CRC), 1989; article 13 of both the International Convention on the Protection of All Migrant Workers and Members of their Families (ICMW), 1990 and the UN Convention against Corruption (UNCAC), 2003, and article 21 of the Convention on the Rights of Persons with Disabilities (CRPD), 2006, guarantee the freedom of thought, conscience, expression and opinion. In fact, most international human rights instruments ranging from global to regional ones have acknowledged the FOE and the press.

\section{Free Press and Restrictions: Bangladesh Constitution and Other Statutes}

The majority of the statutory laws on media or press enacted before or after the Bangladesh Constitution have imposed more restrictions on the freedom of the press than to endorse it. Some laws have their origins in the British colonial period or in the process of decolonization but these laws were retained to control the press. The Constitution of the People's Republic of Bangladesh, 1972 was born with the provision of the freedom of the press and reasonable restrictions. Article 39 entails the spirit of sunshine law over the culture of secrecy with a view to ensuring information oriented participatory governance. The marginal notes of the article engulf the freedom of thought and conscience and of speech. However, article 39(1), guarantees the freedom of thought and conscience, article 39(2) (a) protects the freedom of speech and expression of every citizen, while freedom of the press is assured under article 39(2) (b). But in terms of each enjoyment of each right article 39(2) has envisaged reminded seven to eight reasonable restrictions subject to the law for the interests of State security, friendly relations with foreign states, public order, decency or morality, contempt of court, defamation and incitement to an offence. The restrictions are as follow:

\section{Interests of State Security}

Generally, the freedom of the press is in restriction when there is the apprehension of endangering of the State security. If the words, ideas, and actions intend to endanger the security of the State by crimes of violence, conspiracy to overthrow the government, waging of war and rebellion against the government, external aggression or war, etc. then in the interest of state security, media may be restrained. The provisions of sedition and criminal libel are also practiced to arrest and prosecute journalists and free thinkers. Sedition laws can be applied broadly with harsher penalties ranging from fines to death sentence or life imprisonment if the accused is found guilty to have undermined the Constitution.

The Penal Code, 1860 prescribes punishment for offences committed within and beyond Bangladesh which endanger the national security, the public peace, and the public morale. Apart from the Penal Code, 1860, the Post Office Act, 1898, the Telegraph Act, 1885, the Official Secrets Act, 1923, the Wireless Telegraphy Act, 1933, the ICT Act, 2006, and the DSA, 2018 bear the provisions for restricting press freedom in the name of state security. The insertion of section 124A in 1870 in the Penal Code entails sedition as an offence against 
the State. Under the provision, disaffection towards the government is also a seditious offence. The British government introduced it to punish any attempt of hatred, contempt or disaffection to the British government or its colonial administration. Offences under Sections 123A and 124A are now being tried exclusively by the Special Tribunal under the Special Powers Act of 1974. These two sections of the Penal Code deal with offences endangering the security of the state. Section 99A as added in 1991 to the CrPC, 1898 empowers the government to forfeit and seize any newspaper if it publishes any seditious matter. The security forces of Bangladesh have long track records of arbitrary arrest, enforced disappearance, and extrajudicial killing in the plea of State security which raises serious concerns. The Detective Branch (DB) of the police, the Border Guards Bangladesh (BGB), the Directorate General Forces Inspectorate (DGFI), and the Rapid Action Battalion (RAB) have all been accused of serious violations of laws in the guise of State security.

\section{Friendly Relations with Foreign States}

The addition of section 505A in the Penal Code in 1991 has inflicted a package of restrictions on the press saying:

Whoever (a) by words either spoken or written, or by signs or by visible representations or otherwise does anything, or (b) makes, publishes or circulates any statement, rumour or report, which is likely to be prejudicial to the interests of the security of Bangladesh or public order or to the maintenance of friendly relations of Bangladesh with foreign states or to maintenance of supplies and services essential to the community, shall be punished with imprisonment for a term which may extend to seven years, or with fine, or with both.

Section 3 of the Foreign Relations Act, 1932 restricts publication of any book, newspaper or another document with defamatory information or idea with a view to maintaining friendly relations between Bangladesh and other States. Foreign relation is a sensitive issue and so by irresponsible statements the State is not supposed to be embarrassed in maintaining its relations with other States.

\section{Public Order}

Section 2 of the Special Powers Act (SPA), 1974 prohibits any action prejudicial to sovereignty or defence of the country, friendly relation with foreign States, public safety and public order. It also prohibits enmity or hatred between different communities or classes. Under section 3, the government is empowered to detain a suspicious person for six months without trial aiming at preventing him from doing any prejudicial act. Under section 144 of the Code of Criminal Procedure, 1898, the government can impose temporary orders in urgent cases of nuisance or apprehended danger. The Indian Supreme Court (SC) in Madhu Limaye v. S.D.M Monghyr, AIR 1971 SC 2486, opines that 'public order' includes absence of all acts which are a danger to the security of the State and absence of insurrection, riot, turbulence or crimes of violence, but not acts which merely disturb the security of others. Bangladesh Constitution also allows declaration of emergency under article $141 \mathrm{~A}$ on the grounds of political instability or security and external aggression or internal disturbance. As per article 141B, citizens are deprived of some fundamental rights under articles 36-40 and 42 (right to movement, assembly, association, freedom of speech, press, conscience and thought, profession or occupation and also right to property) during emergency, and the enforcement of fundamental rights may be suspended as per article 141C.

\section{Decency or Morality}

Section 292 of the Penal Code, 1860 prohibits sale, distribution, and exhibition of obscene books, pamphlets, paper drawing, painting, any object etc while section 293 prohibits same offences to any person under 20 years of age. Hurting religious feelings or sentiments of the citizens of Bangladesh by any form of expression is banned under sections 295A and 298.

Section $171 \mathrm{G}$ of the Code provides punishment for furnishing false statements in connection with an election. Moreover, the Indecent Advertisement Prohibition Act, 1963, the Cinematograph Act, 1918, the Censorship of Film Act, 1963, The Code for Censorship of Films in Bangladesh, 1985 has envisaged restriction in these. Under the Pornography Control Act, 2012, the production, sale, distribution of porn movies are prohibited which is considered as a laudable initiative as to compliance of social and religious norms. For making pornography using children, the highest punishment is of 10 years of imprisonment and a fine of Tk 5 lakhs. However, religious liberty is guaranteed under articles 2A and 41 of Bangladesh Constitution. 


\section{Contempt of Court}

The law of contempt is based on the broadest of principles under which the courts cannot and will not permit interference with the due administration of justice. Sections 172-190 and 228 of the Penal Code 1860 while sections 195, 476, 480-487 of the CrPC, 1898 bear the provisions of the contempt of court. Nevertheless, the Contempt of Court Act, 1926 is not balanced between protection of the judiciary and FOE and the press. In Bangladesh, the 1926 Act had been replaced by a new one in 2013. The new Act is relatively lenient as section 4(1) declares that no publication is contempt if it is done in good faith. The High Court Division has declared eight sections of the Contempt of Court Act, 2013 as illegal and unconstitutional for its contradiction with section 27, 108 and 112 of Bangladesh Constitution. But the court still reserves the inherent power to punish anyone whom it finds to have interfered with court proceedings (bdnews24.com, 2013).

In legal journalism, there is less chance to write a story or feature. Also, showing duty towards courts and judges are treated as a solemn obligation of every individual including a journalist. In State v. Swadesh Roy and Another, 12 ADC (2015) 932, the apex court of Bangladesh held that 'any publication during the pendency of any matter in any court of law, which tends to interfere with the course of justice in any substantial or real manner by prejudicing the mind of the public against persons concerned in the case before the case is finally heard, is also contempt." The glaring example has been established in Mianul Hossain and Others v. Sheikh Hasina, 53 DLR (2001) 138, wherein the fact of the case was that she (Sheikh Hasina) gave an interview with a correspondent of the British Broadcasting Corporation (BBC) where she made some objectionable and contemptuous statement undermining the image, honour, dignity, and prestige of the Courts of Bangladesh as a whole and it was held by the High Court Division (HCD) of the Supreme Court (SC) that the application for drawing up of proceeding of contempt of court against Sheikh Hasina, the Prime Minister of Bangladesh are disposed of with a note of desire that the honourable Prime Minister shall be more careful and respectful in making any statement or comment with regard to the Judiciary or the judges or the Courts of Bangladesh in future. The SC in the case of Md. Riaz Uddin Khan, Advocate and Another v. Mahmudur Rahman and Others,(2011) 63 DLR (AD) 29, held that no expression of opinion would be immune from liability for exceeding the limit under the law of contempt of court or the constitutional limitations under article 39(2). If any citizen, while exercising the power of freedom of speech, press and expression tries to scandalize the court or undermines the dignity of the court then the court is under the duty to exercise its jurisdiction under article 108. No person has any right to flout the mandate of law or the authority of the court for the alleged establishment of law under the cloak of freedom of thought and conscience or freedom of speech and expression or the freedom of the press guaranteed by article 39. The SC under article 108 is a court of records and exercises all powers and exercises all powers of such a court including the power to punish the contempt for itself.

\section{Defamation}

The legal provisions relating to defamation creates an avenue for the government to misuse discretionary power. Sections 499, 500 and 501 of the Penal Code deal with defamation in form libel and slander deterring press freedom. Furthermore, the punishment prescribed for this type of offence has been made more severe by requiring a sentence of two years to seven years. The grounds of defamation generally include underestimation or undermining of the character, reputation, profession, business, integrity, false allegation of corruption etc. Indian SC in Saxena v. Chief Justice, AIR 1996 SC 2481, held that the freedom of expression or speech is protected as long as it is not malicious, libelous, untrue and reckless. With the advent of ICT, the cyber defamation has been added as a new dimension. Section 57 of the ICT Act, 2006 with its amendment in 2013 was so fatal for freedom of expression (FOE) and was widely misused. The government has repealed section 57 but added the same provision in section 29 of the DSA, 2018 as a mighty blow to the FOE for both online and social media.

\section{Incitement to Offences}

Instigating anyone to commit any offence is prohibited and punishable under law. Sections 153A and 153B of the Penal Code provide that expressions promoting enmity between classes or inciting students to take part in violent political activity call for penal action. Under these two sections government is empowered to take punitive actions for instances of incitement to offences for the sake of public order. Moreover, section 3 of the Police (Incitement to Disaffection) Act, 1922 penalizes any intentional inducement to the police force to withhold his service or to commit a breach of discipline. As part of this article, some other statutes dealing with the press or media are analyzed below. 


\section{The Evidence Act, 1872}

Section 123 of the Evidence Act, 1872 lays down that no one shall be permitted to get any evidence derived from unpublished official records relating to any affairs of State, except with permission. As per section 124, no public officer shall be compelled to disclose communications made to him in official confidence, when he considers that the public interests would suffer by the disclosure. These two provisions are treated to be a necessary evil for the State.

\section{The Post Office Act, 1898}

Section 27A of this Act prescribes that no newspaper printed and published in Bangladesh without conforming to the rules laid down in the Printing Presses and Publications (Declaration and Registration) Act, 1973, shall be transmitted by post. Under section 27B, it is said that any officer of the Post Office authorized by the Post Master General may detain any postal article if it contains any treasonable or seditious matter which is punishable under section 123A or 124A of the Penal Code, 1860.

\section{The Official Secrets Act, 1923}

Among the laws that thwart press freedom, the Official Secrets Act (OSA), 1923 is a leading one. As one of the blackest laws, it permits public officials to keep official records secret or classified in the guise of public order or state security and to decline divulging information to the media. It is of a colonial vintage and also aims at concealing the malpractices of the British government. The colonial masters imported it to stem the rising demand for transparency in the wake of Mahatma Gandhi's 1921 noncooperation movement. When the world inexorably started moving towards transparency, the British rulers imposed culture of secrecy (Hooper, 1987). Under the law, almost all government information will remain as classified or secret and the disclosure of such information is strictly prohibited to uphold the image and interest of the State.

Under section 3 of the OSA, possessing, obtaining, collecting, recording and publishing any secret official information, code or password is a punishable offence and the punishment may extend up to three years of imprisonment or fine. But, spying or espionage as to any information, idea or work of defence, arsenal, naval, military, or air force or secret official code vilifying the safety or the interest of the State is punishable with death sentence or imprisonment for a term of 14 years. As per section 3A, taking any photograph in a restricted area without the written authority of the government causes liability for the interests of the security of the State and punishment may be up to three years of imprisonment. Under section 5(1), any wrongful communication of information undermining the safety, security, and interests of the State is equivalent to treason and punishable with death sentence or imprisonment up to 14 years. Falsification of reports and forgery of information and documents may yield two years of imprisonment but if such issues cover the interests of the State, the imprisonment may extend to 14 years under section 6. It is observed that the OSA, 1923 has too often been used by various administrations to suppress the freedom of the press.

\section{The Printing Presses and Publication (Declaration and Registration) Act, 1973}

This law under section 7 provides the criteria for declaration of the printing presses and publication of newspapers as well as the registration of books. It also talks about the authentication of declaration in line with section 12 and cancellation of the authentication of declaration in case of conviction of the printer or publisher for moral turpitude as per section 20. Moreover, the addition of section 20A in 1976 empowers the government to forfeit any book or newspaper if it contains any words, signs or visible representations which are indecent, obscene or scurrilous.

\section{The Press Council Act, 1974}

The Press Council Act, 1974 is mandated to preserve and promote the freedom of the press and the standard of newspapers as well as news agencies in Bangladesh as per section 11. Under the same law, the Press Council is a 15-member quasi-judicial body established in 1979 to deal with press related disputes and issues. Under section 11(2) (b), the Press Council has articulated a set of Code of Conduct for newspapers, news agencies, and journalists in 1993. Section 11(2) (d) envisages the sense of responsibility and professionalism for journalists. The quasi-judicial body is also authorized to warn, admonish and censure any newspapers or news agency, the editor or journalist for professional misconduct, breach of the code of ethics after giving them the opportunity to be heard under section 12. Under section 13(2), no authority can compel any newspaper, news agency, editor or journalist to disclose the source of any news or information published by that newspaper or received or reported by that news agency, editor or journalist. It may be treated like a privileged communication like lawyers and clients or doctors and patients. But such protection whether under law or not, a newspaper cannot use fake news sources in the name of confidentiality and non-identification. A journalist may be 
Business Ethics and Leadership, Volume 3, Issue 1, 2019 ISSN (online) - 2520-6311; ISSN (print) - 2520-6761

required to identify his sources before courts or tribunals for the greater national interest or of the interest of justice. Indian SC in Shreya Singhal v. Union of India, AIR (2015) SC 1523, held that the disclosure of source is not required unless the non-disclosure hampers the greater national or public interest.

\section{The Special Powers Act, 1974}

Again the Special Powers Act (SPA), 1974 came up with a suppressive attitude towards the newspapers. It prohibits journalists and media houses to publish any prejudicial report and also grants the State extraordinary discretionary power of arrest and detention without trial. Most offences under this law are non-bailable. Sections 16, 17 and 18 of the Act, in the name of prohibition of prejudicial acts, curtail liberty of the press. Section 19 and 20 curtail the freedom of association and under these provisions, the Government is authorized to impose control over such associations with a view to restricting them to commit prejudicial acts for the maintenance of public order. Section 32 of the SPA creates an embargo to granting bail to a detainee.

\section{Rule 19 of the Government Servants (Conduct) Rules, 1979}

Rule 19 of the Government Servants (Conduct) Rules, 1979 states that a Government servant is not allowed to disclose any information relating to Ministries, Divisions or Departments to any press or other persons.

\section{Rule 28(1) of the Rules of Business, 1996}

Rule 28(1) of the Rules of Business, 1996, restricts direct or indirect disclosure of official documents by a government servant to the press unless he is permitted to do so.

\section{The Telecommunication Act, 2001}

Under section 30(1) (f) of this Act, one of the responsibilities of the Bangladesh Telecommunication Regulatory Commission (BTRC) is to 'ensure protection of the privacy of telecommunication'. The law also contains provisions that allow the infringement of this right in cases of 'national security' and 'public order'. But the section 97A of the Act added in 2006 allows intelligence agencies to tap telephone and mobile phone conversations in order to protect national security and public order. In Bangladesh v. H.M. Ershad, 52 DLR 1997 (AD) 162, the Appellate Division (AD) of the Bangladesh SC held that "neither police officer, nor any other public functionary can enter into the house of any citizen and conduct any search or seize anything unless he is duly authorized under any law." But in practice, the violation of such order is rampant. In India, the SC in Justice K. S. Puttaswamy (Retd.) and Another v. Union of India and Others, Civil Writ Petition No. 494 of 2012 but decision on 24 August 2017, declared the right to privacy as a fundamental right and in comparison to Bangladesh there is less infringement of the right to privacy there. In case of New Zealand, there is a separate Privacy Act, 1993 while Canada has the Personal Information Protection and Electronic Documents Act, 2000 for ensuring the privacy of people and protection of data. The provisions of the amendment in 2010 of the Telecommunication Act, 2001 has made the law tougher as the BTRC can penalize anyone even for sending a wrong text message. Under the amended section 64, BTRC can impose up to Tk 300 crore in fine and five years of imprisonment in the case of non-payment of the fine within BTRC-set timeframe.

\section{The Information and Communication Technology (ICT) Act, 2006}

Sections 54, 56, 57, 58 and 66 of the ICT Act, 2006 by its amendment in 2013 created a huge impediment not only for journalists as to free press but also for all free thinkers and social media users as to FOE. Particularly, section 57 through its amendment in 2013 was able to restrict the FOE for all. Though, sections 54, 56, 57, 58 and 66 are repealed now, the impacts are in persistence in the society.

In case of India, section 66A, a similar provision like section 57 of Bangladesh was added in the Indian ICT Act, 2000 by its amendment in 2008. The misuse of section 66A was widespread for years in arresting persons for critical posting of comments in social media relating to touchy social, religious and political issues. The SC of India in Shreya Singhal v. Union of India, AIR (2015) SC 1523, scrapped section 66A because of its inconsistency with article 19(1) of the Indian Constitution of 1949. In the same case, the SC opined that liberty and freedom of expression are the two cardinal principles of democracy. The SC also said that the section 66A has upset the balance between freedom of speech and reasonable restrictions. The observations of the SC appeared because of the arbitrary, excessive disproportionate mandate of section 66A invading free press with a chilling effect. Here, the SC has prioritized the constitutional provision guaranteeing the freedom of the expression and the press.

\section{The Right to Information (RTI) Act, 2009}

The RTI Act, 2009 heralded a new dawn for the disclosure of information with a view to expediting culture openness through burying the long-standing culture of secrecy. In accessing information of government, semi- 
ISSN (online) - 2520-6311; ISSN (print) - 2520-6761

government, autonomous and other organizations, the RTI Act came up with the rights-based approach allowing individuals and groups to understand the policies and actions of the government and other entities and treat FOE as a catalyst for strengthening democracy, promoting human rights and good governance. Accessing information is treated as a right under sections $2(\mathrm{~g})$ and 4 but the long list of exceptions under section 7 weakens the spirit of the law in the name of state security, integrity, sovereignty, intelligence, and public interest despite its supremacy clause in case of inconsistency with other statutory laws under section 3. However, the RTI Act is a gentleperson's law as the penalty provision is only 5,000 taka (around US \$ 60) which is too scanty. Moreover, the information commission comprising of three members is envisaged with the responsibility to enforce the law but the commission is too weak in terms of its capacity of the workforce to realize the purpose of the RTI Act.

\section{The Public Interest Information Disclosure (PIID) Act, 2011}

The PIID Act, 2011 is another epoch-making attempt to provide legal protection to the persons disclosing information relating to issues of public interest. The person who discloses authentic information to a competent government authority is named as a whistleblower. This law prohibits any civil, criminal or departmental suit for disclosing public interest by a whistleblower but does not protect the whistleblower for disclosing false and baseless information.

\section{The National Broadcast Policy, 2014}

The National Broadcast Policy, 2014 aims at monitoring news, programs, advertisements, talk-show in television and radio. In fact, it restricts the news that harm unity and independence of Bangladesh, spark anarchy, mutiny, unrest, violence, and hatred, invade privacy, impede state security, hurt religious values and non-communal spirit, inspire corruption, ridicule the armed forces and the law enforcing agencies. It also prohibits advertisements undermining the liberation war, language movement and Independence Day along with restricting the scope of advertisement on social and professional issues.

\section{The National Online Mass Media Policy, 2017}

The National Online Mass Media Policy, 2017 emerged suggesting the constitution of a National Broadcast Commission (NBC) to facilitate the operations of online mass media in an organized manner. Under the policy, every online mass media is required to get registration. Under this policy, every online media is to get approval from the proposed Broadcast Commission and the online media outlets are required to have an editorial policy, which may hamper the growth as well as freedom of mass media. Though the government consulted with the stakeholders and took opinions from them, their recommendations are not properly reflected in it. To regulate the online mass media, forming of the independent, neutral and effective broadcast commission is the demanded by the stakeholders concerned but it is yet to be formulated. However, the draft law on the National Broadcast Act 2018 is now in the forefront of discussion and debate. The proposed law bears the provision to form a seven-member National Broadcast Commission (NBC) through recommendations from a search committee and the NBC will be the sole authority to permit licences to broadcast media and the registration of online media outlets apart from the Ministry of Information.

\section{The Digital Security Act (DSA) Act, 2018}

Lastly, the DSA Act, 2018 is the most recent addition to hamper the FOE and the press hampering the free flow of information by stiff penalties for a wide variety of cyber interactions (Freedom House, 2018). The DSA provides for a minimum of seven years and a maximum of fourteen years imprisonment and monetary fines of a minimum of Tk2.5 million and a maximum of Tk10 million, or both, for illegal access and destruction of any important information related to State affairs. Under the law, there will be a 13-member digital security council with the prime minister in the chair. Omitting sections 54, 56, 57, 58 and 66 of the ICT Act, 2006, the DSA 2018 is enacted with harsher provisions to gag press freedom. Most sections including 17, 18, 21, 25, 28, 29, 31, 32, and 43 of the DSA, 2018 are severely draconian than the ICT Act, 2006 and its amended provisions in 2013. Offences under these sections are cognizable and non-bailable allowing police to arrest anyone without a warrant while only a few offences under section 29, 20, 25 and 48 are bailable.

Section 21 of the DSA provides for sentences of up to 14 years of prison for anyone who uses digital devices to spread negative propaganda against the liberation war or the father of the nation, the national anthem or national flag while section 25 introduces sentences of up to 3 years in prison for deliberately publishing intimidating or distorted information against someone in online media. Section 28 mandates the government to imprison anyone up to 10 years for hurting someone's religious values or sentiments whereas section 29 
provides up to 3 years in prison for publishing information intended to defame someone. Section 31 provides for sentences of up to 7 years in prison for deliberately publishing information that can spread hatred among certain communities. Section 32 has been widely criticized by rights groups for potentially stifling investigative journalism as it considers the secret recording of any information at any government, semi-government or autonomous institutions as espionage imposing sentences of up to 14 years. It grants law enforcement authorities wide-ranging powers to remove or block online information that harms the unity of the country or any part of it, economic activities, security, defense, religious values or public order or spreads communal hostility and hatred. In true sense of legislative analysis, it may be stated that the DSA is based on the doctrine of colourable legislation, wherein the government indirectly and secretly has an undue influence on certain sections of a society to materialize its agenda. It may take Bangladesh back to the analogue era with the apprehension of throttling press freedom and dissenting ideas and views. In fact, the colonial mindset or attitude in curbing free press in an independent and sovereign State does not make that much sense in the present context of globalization of human rights.

Lastly, it may be stated that there are around 50 laws directly or indirectly linked with the print, electronic or broadcast media in Bangladesh. In most laws, the anti-press freedom attitude is prevalent while few provisions of some laws generate freedom of the press with reasonable restrictions.

\section{Balancing Free Press and Reasonable Restriction}

Putting restrictions on the freedom of the press is a sensitive issue. Nonetheless, it has been well-established idea that there is no such thing as absolute freedom as it always entails obligations to respect certain boundaries. According to UNESCO, the tool kits of the FOE envision FOE as a complex right because it is not absolute carrying some special duties and responsibilities with it. The right to FOE protects both the speaker and the listener respecting people's right to dignity, safety, and privacy (Bhuiyan, 2015).

The fundamental role of the media has been recognized in several international cases, notably in Thorgeison $v$ Iceland, 13778/88, ECHR 1992, at para 63, in which the European Court of Human Rights (ECtHR) stated:

Whilst the press must not overstep the bounds set, [among other things], for "the protection of the reputation of ... others", it is nevertheless incumbent on it to impart information and ideas on matters of public interest. Not only does it have the task of imparting such information and ideas: the public also has a right to receive them. Were it otherwise, the press would be unable to play its vital role of "public watchdog".

However, restriction on the various forms of FOE including the press is a common phenomenon in every form of government across the globe. There are certain general exceptions to the FOE and such issues include child pornography, hate speech, incitement to offence, contempt of court, privacy and fair trial. Even USA being a champion of free press, imposes certain restrictions under the $1^{\text {st }}$ Amendment of its Constitution. The restrictions include perjury (lying under oath or false swearing), fraud, defamation, obscenity, incitement of panic or crime and sedition. The U. S. Federal Supreme Court (SC) in New York Times Co. v. Sullivan, 376 US 254, held that the $1^{\text {st }}$ Amendment shields criticisms of official conduct and protect public officials from defamation unless performance of public duties involve malice. The SC in Saia v, New York, 334 US 558, also held that the restriction as imposed by law to be reasonable and proportionate not arbitrary. Even Americans are having trust deficit on their media. According to a report, only one out of five Americans has "great deal" or a "quite a lot" trust in news media (Cillizza, 2014). The Privy Council of the United Kingdom, in Hector v. A. G. of Antigua and Barbuda, [1990] 2 All ER 103, 106, held that public administrators are always open to criticism in a free democratic society and barring criticism amounts to political censorship and is unreasonable. However, Collins English Dictionary of the UK has declared "Fake News" as the word of the year 2017. Fake news runs apace while positive news follows snail's pace. The SC of India in the case of Santokh Singh v. Delhi Administration, AIR 1973 SC 1091, held that in determining reasonability of restriction on freedom of speech and expression, a reasonable balance must be struck between the need for the freedom in democracy and social interest preventing disorder and anarchy as per the Constitution. In another case of Life Insurance Corp. v. Manubhai, AIR 1993 SC 171, the SC decided that in case of imposing restrictions, the onus lies on the respondent to show that the denial is authorized by a law imposing reasonable restrictions.

In case of Bangladesh, such restrictions often have crossed the ambit of reasonableness as the colonial mindset of government powers, concomitant vulnerability in nourishing the cultures of democracy, division among journalists and their partisan attitude have taken the grip of the press (Bhuian, 2016). Arguably, the press should enjoy maximum freedoms and minimum but reasonable restrictions encouraging responsible journalism. In order to ensure responsibility in the august profession, the restrictions can be balanced by the 
ISSN (online) - 2520-6311; ISSN (print) - 2520-6761

sense of proportionality. At present, with the advent of ICT and expansion of the tiers of communication, the idea of restriction on press or on media is fading away in other countries but not in Bangladesh. The $21^{\text {st }}$ century has opened a floodgate of openness of all communicative forms including the press and the virtual communications have transcended frontiers with lesser restrictions except few countries like North Korea, China, Russia, Bangladesh, India, Pakistan etc.

Nevertheless, in 2015, the High Court Division (HCD) of the Supreme Court (SC) of Bangladesh in the case of Badiul Alam Majumdar and others v. Information Commission, Bangladesh and another, 69 DLR (HCD) 100 , has outlawed the secrecy of information concerning financial issues of the political parties. The SC observed that political parties operating in the public sphere have constitutional and statutory obligations for accountability and transparency and such financial documents are public documents under section 74(2) of the Evidence Act, 1872. But, abuse of the power in the guise of press freedom may be more damaging and so reasonable restrictions are also sought to control the wildness of the press or media. Sometimes, yellow journalism, embedded journalism, aggressive journalism also causes restrictions of press freedom and in such occasions, journalists cannot avoid responsibility. In Bangladesh, a satire magazine named Alpin was suspended by the government because of its objectionable contents (Majumdar, 2007). The trend of 'if it bleeds, it leads' is not a proper way for an objective press or media.

At the same time, social media users also need to learn the limits of their means of FOE. Spreading false, fabricated or distorted information or image, defamatory comments, hate speech, issuing threats through posts and messages in various forms of social media including Facebook, Twitter, LinkedIn, Instagram etc. instigating violence must not be protected in the name of FOE. Every press is supposed to follow five ethical principles such as truth and accuracy, independence, fairness and impartiality, humanity and accountability (White, 2015).

But sometimes journalists are involved in following seven deadly sins (Harrower, 2005) forgetting the values of their profession.

I. Deception in the form of lie or misrepresentation of information.

II. Indulging in the conflict of interest through acceptance of gift or favour for personal, political or social causes.

III. Slanting quotes or imaginary sources to fabricate or exaggerate news and views.

IV. Manufacturing quotes or imaginary sources.

V. Unlawful obtaining of information from a source.

VI. Deceiving and betraying the confidence of those who provide information.

VII. Doing plagiarism through passing off someone else's words or ideas as own.

It is believed that if freedom of the press is not ensured then other destructive forms of journalism engulf and emerge with the aid of partisan politics plunging the nation into the ditch of uncertainty and volatility (Zamir, 2018). With respect to governmental information, any government may determine which sorts of information are open to all to seek and disseminate and also which materials and information are protected as sensitive, classified or secret from public disclosure in the name of national interest or state security. In 2017, a U.S. based nonprofit body, the Freedom House, found that only 13 percent of the world's population enjoys a free press and the safety and security of journalists are at risk (Dunham, 2017). It has been visible that restrictions are harsher, the vulnerability of democratic values, rule of law and respect for human rights with human dignity are in shambles. There are examples that showing the gray area of State interest, some states are taking preemptive or preventive measures against the media corrupting the solemn idea of reasonable restriction.

On June 16, 1975, in Bangladesh, all newspapers were banned by the then government except the State patronized four newspapers and this day is known as the black day in the history of newspapers in Bangladesh. On that day, all newspapers (29 dailies and 138 weeklies and periodicals) except four namely the State-owned The Dainik Bangla and The Bangladesh Times; and privately owned and later nationalized The Daily Ittefaq and The Bangladesh Observer were closed by the government. The Martial Law Regulations, 1976 prohibits criticism of the imposition of martial law and made it as a seriously punishable offence. Similarly, on 17 August 1975, the burial news of Bangabandu Sheikh Mujibur Rahman was restricted to report by the press. The Dainik Bangla carried out a tiny Bangladesh Sangbad Sangtha (BSS) report, which was literally of one short paragraph in length, and the report read:

"Former president Sheikh Mujibur Rahman's body was taken to his village at Tungipara in Faridpur on Saturday by air and buried in his family graveyard with full respect (Manik, 2014)". 
In most cases, the government treats media as a government property whose main task is to support and facilitate government. Also, the aggressive demand for absolute freedom by the media can be portrayed as a truck with a dysfunctional break. So, neither an aggressive nor a lapdog press rather a responsible press can reshape the society towards the desired change ensuring people's right to know, right to share and right to participate in decision making of societal and government functions.

Evidently, responsible journalism is an accepted notion to protect press freedom. Both freedom of the press and responsible journalism are cooperatively intertwined not in conflict with each other. Journalism is a profession in which there are more responsibilities than rights to be claimed by journalists. It is said that if a teacher teaches a wrong content, his students may suffer for it but if a journalist put any wrong information or source, the entire nation suffers for it. Sometimes, the sufferings can cross the national boundary and affect the international community. So, the concept of press ombudsperson may be considered in balancing free press and reasonable restriction. In Bangladesh, The Daily Amader Somoy had a press ombudsperson to ensure responsible journalism but the role of the position is quite insignificant.

Under article 20 of Bangladesh Constitution, every citizen is prescribed to carry out professional work as a right and duty while article 21 necessitates the duty of every citizen to observe the Constitution and the laws, to maintain discipline, to perform public duties and to protect public property. Under articles $36,37,38$ and 40 , all journalists and other employees involved in the press industry have a right to movement, engage in association and assemble coupled with freedom of profession to realize their legitimate demands through peaceful means, not by violent ones.

Article 70 also creates a hindrance for freedom of speech. There is no scope to raise judicial voice against the functions of the parliament as a member or official of the parliament is immune under article 78 of the Constitution. So, the scope for investigative reporting is also limited under the theme of this article. However, the SC in a case of 51 DLR 1, para-11, citing Constitutional experts in Bangladesh opined that the article 70 was framed to ensure the stability and strengthen the parliamentary democracy because of previous bitter experience of floor crossing and horse-trading. In 2011, the $15^{\text {th }}$ amendment to the Constitution includes language in article 7A that equates criticism of the constitution with sedition. The Appellate Division (AD) of the SC in Bangladesh v. Md. Abul Hossain, 2003 BLD (AD) 129, held that once the privilege is given to a person on condition of doing any act and if such condition is fulfilled, such privilege or right cannot be taken away or canceled without giving him a chance of being heard. This judicial precedent is an example of legitimate expectation. In balancing press freedom and reasonable restrictions, the social responsibility theory may be utilized believing objective journalism can change the society. This theory offers media freedom on the one hand and external control, on the other hand, creating a synergy between the free press and responsible press. Moreover, Jeremy Bentham's pain and pleasure theory (hedonism) may be considered positively. Hence, the government should inflict lesser pain and ensure maximum pleasure for a larger number of people as to the free press.

As part of international legal obligations, Bangladesh is obliged to comply with the international human rights instruments in which she is a State party. The country cannot deny its obligations showing lame excuses. In the case of Bangladesh, it is observed that the restrictions under article 39(2) of the constitution are not in conformity with those suggested under article 19(3) of the ICCPR. The scope of article 19(3) under the ICCPR in putting restrictions on press or media is lesser than those of article 39(2). ICCPR is more balanced on the right to privacy but the State often violates the right to privacy of citizens in the name of national interest. As per article 32 of Bangladesh Constitution, 1972, no person shall be deprived of life or personal liberties save in accordance with law while article 43 guarantees the privacy of home and correspondence and in communications. So, any interference with the right to privacy and FOE should be based on the clear provision of law reflecting legitimate reasoning and proportionality with minimal interference necessary. Similarly, the restrictions on the basis of friendly relation of foreign states are to be in parity with reasonableness and objective satisfaction.

Bangladesh is obliged under the International Covenant on Civil and Political Rights to protect its citizens from arbitrary arrest (article 9), from arbitrary or unlawful interference with their privacy and correspondence (article 17), and their freedom of expression (article 19). Peaceful criticism of the government and state authorities should always be permitted.

As per the observation of the Reporters Sans Frontiers (RSF), a global think-tank of journalists, media selfcensorship is growing in Bangladesh as a result of endemic violence against journalists and media outlets. All journalists and free thinkers including outspoken secular bloggers and writers are scared of it. Even the female journalists are not spared from the curse of violence (Reporters Sans Frontiers Report, 2018). According to a 
report, about 20 journalists were killed in Bangladesh from 1992 to 2016 but there is no evidence of prosecuting the killers (Singhvi, 2016). In commemoration of the assassination of two French journalists in Mali on 2 November 2013, the UN General Assembly adopted a resolution A/RES/68/163, in 2013 and proclaimed 2 November as the international day to end impunity for crimes against journalists. The landmark resolution condemns all attacks and violence against journalists and media workers. It also urged the UN member States to do their utmost to prevent violence against journalists and media workers bringing the perpetrators to justice so that the victims have appropriate remedies. It further calls upon States to promote a safe and enabling environment for journalists to perform their work independently and without any undue interference. Moreover, the comments and guidelines of the UN Human Rights Council, reports and observations of various committees under different human rights treaties and directions of the regional human rights bodies are to be followed to justify the reasonableness of restrictions on press freedom.

\section{Impacts of Free Press and Reasonable Restrictions: Past, Present, and Future}

In the absence of free press, malpractices or maladministration, corruption, money laundering, misappropriation of government funds etc. may increase rapidly. George Sutherland, an English-born U.S. jurist and politician said that a free press stands as one of the great interpreters between the government and the people. He further said that to allow a free press to be fettered is to fetter people of that country. The President of the People's Republic of Bangladesh Abdul Hamid says:

During the Pakistan period, newspapers of the land stood courageously against the oppression and discrimination of the Bengali people by West Pakistani ruling cliques, vocally asserting the common man's demand for the right to freedom. During the Liberation War, the international media were instrumental in creating global public opinion in favour of the cause of our freedom struggle. After independence, newspapers devoted their creative energy to the rebuilding of the war-torn nation. In all these years, most newspapers have maintained a secular and democratic stand and played a patriotic role at various critical moments of the country. They voiced the woes of the downtrodden people of the society to establish their rights. Their intellectual input to planning and implementation of various development policies such as women empowerment, poverty reduction, urban and rural development is well recognized (Hamid, 2016).

He again says that you (press) may criticize the government keeping in mind that it should be based on fact not on fiction or bias as constructive criticism can play an important role in taking the right decision for running the government and building the nation. The government usually depends on two sets of sources for information i.e. official source and independent media. For credible and authentic information, independent media is more reliable than the complacent and fabricated information emanating from bureaucrats. After a glorious revolution in 1917, the Soviet Union collapsed for many reasons including excessive dependence on bureaucratic information and unreasonable restrictions on media. As per the advice of the Islamic clergymen, the Ottoman Empire banned the printing presses for 200 years showing the reason for non-Muslim ownership of all the presses until 1726. It is one of the major causes of the relative decline of Ottoman science and culture in comparison to Europe. Mahfuz Anam, the editor of the Daily Star says:

"Has the world been served better because of Wikileaks, Panama papers and Paradise papers? Under the law in question, all Bangladeshi whose names appeared in those papers could have taken us to court and the police could have arrested us for publishing secret documents (Anam, 2018)".

In March 2017, Facebook authority refused to sign a Memorandum of Understanding (MoU) with Bangladesh police, who had asked Facebook to demand additional identification, including National ID numbers, from Bangladesh nationals who want to sign up to the social network. In 2018, social media, particularly Facebook, played a significant role in nationwide protest movements calling for better road safety and protesting a quota system used to fill certain public service and other positions. Protesters used Facebook to mobilize, and both protesters and the government used it to express their positions. Photos and videos were shared using the hashtags \#WeWantJustice, \#RoadSafetyMovement, and \#Bangladeshstudentprotests drawing massive support from people of all walks of life.

Despite being partially free and less vibrant media has served Bangladesh in many national crises including during the war of liberation. It has contributed significantly to improving the image of the country and of its democracy. The DSA, 2018 will hamper both the FOE and the press in all forms. The New York-based Committee to Protect Journalists (CPJ) published a recent report depicting that the dividing line between politics and journalism is "more blurred than ever" in Bangladesh. The country is experiencing a decline in press freedoms and journalists are attacked from all sides\| and have very low life security (Farhana, 2014). It 
is to be noted that between 2012 and June 2017, a total of 1,417 cases were filed under section 57 of the ICT Act- a whopping 65 percent of them for defamation. As high as 65 percent accused were acquitted by the court after or during the trial. In addition, police did not even find any merit to frame charges in some 180 cases. This makes it clear how the ICT Act particularly section 57 is abused to gag freedom of press, speech and other forms of expression (Rabbi, 2018).

Following the declaration of unconstitutionality of section 66A of the Indian ICT Act by the Indian SC, journalists, rights activists, and free thinkers demanded to repeal similar section 57 of the ICT Act, 2006 as amended in 2013 with tougher legal actions. In the wake of widespread criticism, the government has recently repealed the section 57 of the ICT Act in 2018 but has kept its contents in several provisions of the DSA, 2018 allowing police more arbitrary powers. Some provisions of the DSA, 2018 are even more draconian in comparison to its predecessor and can be used against dissidents.

The newspaper editors' council in Bangladesh has raised concerns on at least nine sections of the DSA, 2018 fearing further obstructions on the FOE and the press. It may be opined that the freedom of the press in the country started blooming from 1990 with the restoration of democracy but is fading with some draconian laws. Throughout the history of the country, it is seen that the democratically elected governments are more respectful towards freedom of the press with reasonable restrictions than the military-backed governments.

To understand the presence of freedom of the press and reasonable restrictions in a country, it is imperative to understand the historical, political, economic and cultural dimensions along with the legal environment of that country. Bangladesh is a politically polarized country and the press industry with privatized or public ownership is also highly politicized with numerous groupings. Privatized media to some extent except decisive political issues like national poll shows impartiality in accessing and disseminating of information, ideas and views but prioritizes its commercial or corporate interests while the State-owned media is only covering positive news stories of the government and exploding the negative news of the opposition political parties. Seemingly, journalists of the State-owned media in Bangladesh are bound to serve the government otherwise they are likely to lose their jobs. In fact, most journalists in State-owned media are changed with the change of government with different political parties. The government is seemingly complacent with the positive data presented by the State-owned media and it expresses backlash against the privately owned media. In the case of the State-owned media of the country, the restriction is imposed by the respective governments. But in some other countries, the State-owned media like BBC, Al Jazeera are not absolutely controlled by the government. A media whether State-owned or privately owned needs to secure its national interest and sovereignty than the interests of journalists or other vested quarters.

A fundamental tenet of a free press is the ability to access information and in doing so, to keep sources safe and confidential. As the press is partly free, uncensored and unhindered, it cannot play its desired role. When we see the recent trend of government attitude we can find that press freedom has randomly been violated in Bangladesh in many ways. This strategy matches with the then prime minister of Singapore Lee Kuan Yew who in 1971 said that the freedom of the press must be subordinated to the overriding needs of the integrity of a sovereign territory. No country on earth except China to a large extent or Singapore to a little extent has benefited from curbing free press and freedom of expression (Yew, 1971). A united media has had glorious roles in different developments in Bangladesh's history including its independence. Prominent journalist Manik Miah inspired the common masses during independence (Jahangir, 2015). However, the situation has changed recently as the journalist community has become more divided and influenced by the political ideology of the owners of certain media, a development that is sometimes reflected in the journalists' writings and reports. Even in the case of developing professionalism in the field, ensuring better wages and job security, the journalist community is not united.

The ownership of media outlets by the politicians, business persons, and influential ones is also a cause of concern for the free and responsible press. Apart from oppression on journalists, the groupings and division among the different representative bodies of journalists including the Newspaper Owners Association of Bangladesh, Newspaper Editors Council and Association of TV Channel Owners are responsible for the present status of media freedom. Also, the polarization among the various journalistic associations such as National Press Club, Bangladesh Union of Federal Journalists, Dhaka Union of Journalists, Reporters Unity and many other organizations expose threats to free press. According to a survey report, $57 \%$ of readers are skeptical about media reports while $43 \%$ of respondents are positive about media reports (Hasan, 2018). All of the above circumstances have been weakening the voice of journalists and free thinkers in upholding and protecting freedom of expression and press in the country. 
ISSN (online) - 2520-6311; ISSN (print) - 2520-6761

Nonetheless, the press must have public trust and confidence while carrying out its professional functions otherwise press freedom can bring disaster for the society. However, like the people of the entire world, Bangladeshi people have also witnessed the role of Julian Assange and Edward Snowden- two most dominant whistleblowers in disclosing a large volume of classified documents. As the number of media and media houses are increasing rapidly, the future of press freedom is likely to increase and restrictions to go down gradually. At present, according to the Ministry of Information report in 2016, there are 1,086 daily newspapers, 41 television channels, 28 FM stations and 32 community radio stations in Bangladesh while 1,700 online news portals have applied for registration. It is better not to express cynicism or skepticism rather to express optimism as to the betterment of the FOE and free press in the days ahead.

\section{Reasonable Press, Democracy and Citizens}

Theoretically or ideally, the voice of the press is treated as the voice of the people aiming at ensuring check and balance of government functions. In fact, the press is not an enemy of a government rather it is supportive to the government. Hence, censoring the press means the suppression of people's voice.

It is said that a popular democracy without a balanced interconnection between citizens and free press is a farce or a tragedy. The need of the FOE and the free press in combating corruption and ensuring transparency and accountability can never be underestimated. If the press is lenient to corporate interest and works as a vehicle of propaganda, it loses its credibility. As a result, the press must be supportive and critical in discharging its neutral functions. Media and democratization are closely interrelated. The presence of a vibrant media is a sine qua non for democracy to survive, grow and flourish. Constructive criticism can play an important role in taking the right decision for running the government and building the nation.

Mahatma Gandhi once said:

"One of the objects of a newspaper is to understand the popular feeling and give expression to it, another is to arouse among the people certain desirable sentiments, and the third is the fearlessness to expose popular defects".

Media can foster open public debate and information exchange which is vital for a democracy to flourish, and a democratic environment, in turn, can lead to the development of better media structures that respond to the concerns of people enhancing the notion of good governance amid transparency, accountability, predictability, and participation.

The SC of Pakistan in the case of Farid Ahmed v. West Pakistan, PLD 1965 Lah 135, held that without a free press there cannot be any democracy. The SC of India in Secretary, Ministry of I \& B v. Cricket Association of Bengal, AIR 1995 SC 1236 at 1293, held that the freedom of the press is the foundation of a democratic society and the court in Union of India v. Motion Pictures Association, AIR 1999 SC 2334, held that press freedom is essential for the rule of law and liberty of citizens. The SC of India in M. Nagaraj v. Union of India, (2006) 8 SCC 212, at p. 214, held that the concept of open government is the direct result from the right to know which is implicit in the right of free speech and expression guaranteed under Article 19 (1) (a). In Dewan Abdul Kader v. Bangladesh, 46 DLR 596 at p. 599, the SC court held that freedom of speech is a right to express one's own opinion absolutely freely by spoken words, writing, printing or in any other manner which may be open to the eyes and ears while expression may also include comments, explanations, annotations, solutions and answers to questions on the ideas expressed by others.

However, the path towards democratization and media development is rocky, and obstacles can include continued interventions by traditional (often governmental) or new (often commercial) power structures. Weak democratic institutions are a threat to the independence of the media. Conflicting and irresponsible media can be a threat to a fragile democracy. Press works as watchdog or whistleblower that not only barks but also bites depicting the social disorders and discrepancy. Independent and pluralistic media promote people's participation in various decisions making and provide an opportunity to other stakeholders as to the sharing their voice. Media freedom can benefit the government by providing information on what is really happening so that governments can adjust policies or correct any mistakes. The greatness of a newspaper is not measured by the size of its readership but by its influence and credibility. However, the absolute power of media may be a threat when its ownership is mostly private and concentrated in the hands of a few. In such situation censoring media is not a solution rather there may be proper regulation by the government or to let the consumer choose which media outlet they want to read, view or listen. It is true that governments in most developing countries fail to see the role free media plays in informing the government. But without critical evaluation of democracy and development of a State by independent and pluralist media outlets, the State remains malnourished and 
imbalanced in attaining good governance. Free, pluralistic and independent press or media is creating a delicate balance among government, society, and citizens paving the way for flourishing democracy and development.

\section{Opportunities and Challenges}

A free, unbiased, accountable and vibrant media informs the public and policymakers through the dissemination of authentic information and creates space for diversified views regarding socio-economic and political processes accelerating people's scope for democratic participation (Hudock, 2003). In Bangladesh, where democracy and State institutions are in their nascence, the mass media's operation despite being partially free is the main way of examining governance and demanding accountability from state machinery (Kabir, 2003). In fact, freedom of the press is intertwined with the prevailing condition of democracy, rule of law and good governance. As a result, the expectation of freedom of the press is unthinkable and a mere eye-wash without the presence of strong democracy with rule of law and elements of good governance. Simultaneously, freedom of the press without transparency and accountability may end up in sensational or yellow journalism impeding the democracy and destabilizing the fabric of good governance. So, free press and accountability of the press go hand in hand to support each other. For ensuring accountability of journalists, there should be a strong code of conduct for them along with its effective implementation mechanism.

The legal restrictions except a few are the core challenges for a free press in the country. Simultaneously, the political and corporate ownership of media also affects the practice of FOE including the press freedom. Sometimes, owners or their representatives advise the newsroom not to publish certain types of news stories which hamper their interests. Occasionally, if any news runs against the business interest of the media houses and their policies, then that news never sees the light of day. And, in the same vein, in cases where the media owners belong to a political party or a corporate group, that particular media outlet often refrains from publishing news hostile to its owners' political ideology or corporate pressure. When religious and political ideologies generate a sense of unity and purpose of journalism, then these divide people and society posing ultimate threat to free press and media. Recent use of social media for fomenting violence through misinformation, disinformation, and hatred has been used against ethnic groups in Myanmar and Sri Lanka. In Bangladesh, the overuse of social media for political purposes cannot be denied. There are pieces of evidence of misuse of social media by vested quarters through the politicization of spontaneous protests of students from even schools and colleges to yield political dividends. Politicians from both ruling and opposition parties wait to politicize any movement or protest deliberately to deteriorate law and order blaming each other using conspiracy theory and blame game.

In nearly 50 years of independence, the nation is striving to rectify the political instability and disorders. If politics in the right order, almost all things including freedom of the press may be in the right track to guide the nation towards plurality, inclusivity, and prosperity amid sustainability. In spite of division, journalists and media activists are striving for ages towards a free press. However, the core opportunities and challenges of press freedom are given below:

\section{Opportunities}

1) Freedom of the press can drive the State and society towards the right direction and can pave the way to a solidified nation. A free press amid reasonable restrictions can work to serve the society better and can keep national interest intact.

2) There is a wider scope to stimulate the existing magnitude of press freedom by repealing some controversial legal provisions for expediting democratic functionality amid good governance through eradication of malpractices of government, semi-government and other entities.

3) Strengthening of the press institute of Bangladesh (PIB) and the press council of Bangladesh (PCB) to hold journalists, freethinkers, media activist and CSOs just, duty bound, transparent and accountable is possible and of urgent necessity.

4) The government especially the Ministry of Information can take steps to create mutual understanding among the media houses, journalist organizations and the regulatory bodies regarding their reciprocal rights and duties.

5) There is a strong chance of institutionalization of media outlets of all print and electronic ones as only a few of them are institutionalized among the large bunch of them. Online news portals are mainly lagging behind in institutionalization.

6) Self-censorship can be justified with the needs of reasonable restrictions, not on personal, political, corporate or other forms of vested interest. 
ISSN (online) - 2520-6311; ISSN (print) - 2520-6761

7) If the government allows press freedom for the State-sponsored media, it may help government policymakers to rectify its wrongs through constructive criticism unearthing the misdeeds of government machinery.

8) Similarly, with the sense of responsibility, the press or media can work towards strengthening the sovereignty and integrity of the nation. It is the duty of the press and media to build an environment where the people of the country can cultivate unity and harmony, not polarization.

9) In the current milieu, media as watchdog is at a transitional stage but there is a large scope for its expansion of social role, the wider framework of operation, greater competition and increasing professionalization.

10) Globally the free press is booming and in Bangladesh, with the increasing number of media outlets, there is a strong possibility for acceleration of the FOE and free press.

\section{Challenges}

1) The absence of press freedom can accelerate malpractices in administration and weaken the State institutions on which the transparency and accountability of various functionaries of government depend on.

2) Some legal provisions under some laws of Bangladesh including the Penal Code, 1860, the OSA, 1923 and the DSA, 2018 are very detrimental to freedom of the press both in print and electronic forms.

3) The colonial 'we v. them' attitude of the government on the one hand and the partisan affiliation and disorganization of the journalist community, on the other hand, pose major threat to free press or media.

4) Deviation of media from its true responsibility towards society and over engagement for corporate or commercial purposes diminishes its integrity and social acceptance.

5) Like a group of Ostrich, journalists, freethinkers, media activists and civil society organizations (CSOs) are often driven by self-interest or vested interest, leading them to adopt self-censorship. Also, the growing self-censorship on media outlets as a result of endemic violence against journalists, free thinkers, and bloggers along with media activists is a genuine impediment towards a free press. Self-censorship vitiates the objectivity and authenticity of journalism and its professional excellence.

6) Like the UK, USA, India, Pakistan and many countries, the ownership of most media outlets in the country goes to corporate business houses, influential persons or politicians. These newspapers or media houses are driven by privatized attitude, progressive-capitalistic and corporate values serving vested interest posing threat to national interest.

7) The economy of media outlets is heavily dependent on an advertisement from both public sector and private companies. As a result, the press usually has a flexible attitude towards negative news about its advertisers, fearing that otherwise, they may lose advertisements.

8) Division among different representative organizations of journalists because of their political affiliations, personal, group and vested interest along with cynicism or skepticism of people as to their trust or confidence on media outlets generate government sanctions on FOE in all forms of media.

9) Lack of awareness of general masses because of their backwardness on educational, economic and social conditions facades free press and vibrancy of other forms of media in Bangladesh.

10) The regulatory bodies of the press or media like the press institute of Bangladesh (PIB) and the press council of Bangladesh (PCB) are not playing their due part because of their incapacity and overpoliticization requiring institutionalization in the true sense.

11) In the case of media outlets, only a handful of them is having institutionalized character while most of them are exposing partisan attitude with value-loaded interest than being objective.

12) Abuse of press freedom by newspersons not only generates threat to them but also to the media houses creating an opportunity for the government to curb press freedom in the name of different restrictions.

13) The quotation of Mark Twain i.e. "if you don't read newspaper you will be uninformed but if you read newspapers you will be misinformed" is true in many angles and is still a big challenge for Bangladeshi media. Seemingly like Napoleon Bonaparte, the rulers of the country fear the newspapers more than a hundred thousand bayonets.

\section{Findings and Recommendations}

The culture of secrecy is deep-rooted and perhaps it needs time to establish the culture of openness to thrive. Bangladesh as a developing country cannot deny the global reality of press freedom and its restrictions. According to a report less than $14 \%$ world population live in countries with a free press (Manuli, 2013). In many developing nations, governments and ruling political parties consider press as one of the biggest 
obstacles to development and national interest. From a 2017 report of Freedom House, an American organization which assesses the status of press freedom of different countries every year, the press of Bangladesh was found to be partly free. In Bangladesh, the reality is that the successive governments have resorted to suppress press freedom through various means including regulatory measures to perpetuate their vested political interests. Apart from restrictions on press or media under the existing statutory laws, some other factors such as lack of institutionalized character of the press and the ownership of press by politicians and business people are the major barriers towards free press in the country. Politicians cannot avoid liability for the present condition of the press freedom because they also lag behind in nourishing and practicing the better political culture to change the political landscape of the country paving the way for positive change in the domain of the press or media. Also, because of existing immunity or impunity, the secrets of government officials as to their misjudgments, incompetence, misconduct, venality, cupidity, corruption, or criminality are not exposed.

Moreover, the politicization of media outlets and unfair competition among media houses as to news and views undermines the accountability of journalism and offer government chance to impose restrictions on the freedom of the press. Undoubtedly, some provisions of various statutory laws restrict FOE and freedom of the press violating the spirit of article 39 of the Constitution. These restrictions also go against the mandate of the UDRH, ICCPR and some other international legal instruments undermining democratic values. As compared to other forms of governments, press and media enjoy more freedom in a democracy. Political scientists opine when communication systems are subject to formal political control as in socialist, fascist or authoritarian regimes - the media becomes little more than a propaganda machine (Heywood, 2000). In an emerging democratic society, the media empowers social groups through the dissemination of true news and views and guard the public officials against misuse of powers. The question of the freedom of the press and media is an issue that still goes unsettled on the point whether the press should be allowed to enjoy absolute freedom. It is agreed that too much censorship of press and media is bad. At the same time, every press needs to publish impartial and unbiased news so that it does not instigate the people against the Government to resort to violence. So, the freedom of the press and reasonable restrictions are in need of delicate balance. Some core findings and recommendations are as follow:

\section{Findings}

1) Some provisions of existing Bangladeshi laws on the press have taken away the freedom of the press or media and the ambit of reasonable restrictions has been too much impeding the fabric of democracy, rule of law and good governance amid transparency, accountability, predictability, and participation.

2) Freedom of the press is partially enjoyed by the media in Bangladesh because of direct and indirect restrictions under the existing statutory laws and self-censorship.

3) The idea of freedom of the press is not absolute rather qualified subject to reasonable restrictions and press freedom does not mean transforming the truth into the lie and vice versa. On one hand, absolute press freedom is neither possible nor desirable and on the other hand, the term reasonable restriction demands proportionality and reasonability.

4) There are instances of misuse of press freedom for personal, political and vested corporate interests ignoring the priority of national interest or public interest. Social media and online blogs are also centred to personal, political, corporate or other forms of vested interest.

5) Abuse of freedom of the press tends to gain momentum before any election or referendum in wooing or emotionally blackmailing the voters applying the false propaganda or claims with osmotic effects within a society. Even abuse of media on the national election on 30 December 2018 cannot be overlooked.

6) Some provisions of the existing laws including the ICT Act, 2006 and the DSA, 2018 are inconsistent with articles 7, 26, 27, 31, 32 and 39 of Bangladesh Constitution guaranteeing FOE amid reasonable restrictions.

7) Media in Bangladesh suffers from a trust deficit for many reasons including a lack of experience and professionalism. As a result, politicians, criminals, and businessman exert undue influence to get benefits by exploiting the media.

8) Because of privatization of the print and electronic forms of media, influential business persons and politicians are getting the ownership of them. The owners are targeting the maximization of profits forgetting the true purpose of media outlets.

9) To some extent, media is widely seen as a tool of empowerment for people in Bangladesh but successive governments have failed to realize it rather they compete with each other to curb the FOE in all forms of media. 
ISSN (online) - 2520-6311; ISSN (print) - 2520-6761

10) Without improving the social, economic, political and cultural dimensions, expecting desired freedom of the press is not worth thinking. At the same time, media can be held liable for surface reporting in lieu of investigative journalism involving 360-degree approach.

11) From the British to Pakistan period and from the Pakistan period to the journey of independent Bangladesh, the FOE has been suppressed in the country by the politicians imposing unreasonable restrictions that impeded good governance.

12) Dysfunctional statutory bodies like the Press Institute and Press Council also add insult to the injury of press freedom. The political division of owners of media outlets, the polarization of journalists, media activists, and their representative organizations are also responsible for the present status of the freedom of the press.

\section{Recommendations}

1) Without imposing harsh restrictions, FOE and freedom of the press should be protected and promoted in parity with responsible, transparent and accountable journalism. Simultaneously, reasonable restrictions should be maintained and the journalists should obey the code of conduct, social norms, and values in the dissemination of news, views, images and audio-visual clips.

2) Press freedom should not be used to distort information vilifying the professional attributes of journalists who are considered to be the conscience of a nation. Journalists and freethinkers should remember the maxim "salus populi est suprema lex" meaning public welfare is the highest law.

3) Measures should be taken to amend or repeal the draconian provisions of statutory legal instruments obstructing free press and other forms of FOE and to comply with the standard of international human rights instruments in which Bangladesh is a party.

4) Journalists, freethinkers, bloggers, press activists have to keep in mind that the news, views and other forms of expression should be the reflection of truth, authenticity, impartiality, fairness, and accuracy not prejudice, pressure, bias, or gift and bribery. Newspapers should hear both sides before reporting and reveal the sources of information respecting laws, code of ethics and privacy issues.

5) With the rise of social media, digital literacy and digitization of press, a comprehensive set of ethics should be formulated and enforced to create awareness and sense of compliance to all especially to journalists, freethinkers, and media activists.

6) Sustainability of press freedom amid reasonable restrictions should be ensured catering to the needs, rights, and responsibilities of the State, people, journalists and media outlets. In imposing reasonable restrictions, the sense of reasonability, proportionality, legitimate expectation, convenience and inconvenience of state security and free press should be considered justifiable.

7) Journalists should shun themselves away from partisan political affiliation, polarization or groupings rather they should be more united and professional reflecting independence, honesty, impartiality, courage and ethical standard. There may be a difference of opinions among them but they should be imbibed with the sense of mutual respect and tolerance for the greater interest of freedom of press or media. Exaggerated journalism may be avoided by two ways either by rejecting the agenda-setting through curious and investigative reporting and rejecting the anonymous sources.

8) All stakeholders of a free press should bear in mind that temporary benefits and political favour do not sustain a healthy environment for the press rather demolish it. But, responsible journalism can inculcate more freedom of the press overcoming the perils of the yellow or biased journalism. For ensuring responsible journalism, press ombudsperson can be a positive thought.

9) Only laws alone cannot secure the FOE or free press. In order to ensure the FOE or free press, there is an exponential necessity of tolerance and respect as to dissenting ideas and opinions based on truth and accuracy not on obscurity, fallacy, and fiction.

10) Media houses should be institutionalized and united irrespective of their affiliation and stance to any group, corporate body or political affiliation for the functionality of FOE.

11) Government regulatory bodies like Press Council and Press Institute should be strengthened so that they can regulate the media houses properly. For broadcast media, there should be a broadcast commission for their proper governance.

12) Concerted efforts of all stakeholders are needed to overcome the impediments of the FOE including the press. The government, owners of newspapers, journalists, freethinkers, bloggers, media activists, and CSOs should cooperate and collaborate in setting the boundary of the freedom of the press and reasonable restrictions balancing the interests of all. 


\section{Concluding Remarks}

Freedom of the press is very crucial and it bears resounding implications for every individual in accessing and disseminating information in a society to raise voice against the malpractices of the government and other entities. A free press is an important indicator of a democratic society and sustainable development. If free press prevails in a country, other democratic rights and freedoms will eventually be ensured. However, the privatized press is more interested to serve its commercial purposes and publishing negative news of doom and gloom rather than positive or success stories of governments necessitating reasonable restrictions occasionally. Sometimes, people lose trust in media when it is serving politically motivated agenda and dubious propagandas undermining public interest and social benefits. In spite of the gradual increase of the number of press in the country, the trend of press freedom is on the wane worrying the conscious section of people. To a large extent, the shield of reasonable restrictions is abused by all the governments unjustifiably limiting freedom of the press, speech, targeting journalists, protesters and other persons with dissenting news and views. Even the blocking or filtering of online and social media is now an augmented reality. The successive governments of Bangladesh especially military based ones have treated press freedom as a threat against their ruling regimes. Arguably, the procrastinated clock is ticking as to balancing the freedom of the press and reasonable restrictions. However, apart from the restrictions by the governments, the polarization, partisanship, self-seeking attitude of the journalist community and the told and untold pressure of the owners of press and corporate bodies hinder the freedom of the press and create a dilemma for the reasonable restrictions. There was a crackdown on media in the past, is at present and ostensibly will be in the future. The unity of journalists and media personalities can ease the suppression on them and media houses accelerating the freedom of the press for the greater interest of society. Ultimately, the government in collaboration with the pluralistic, diverse and independent media can create a conciliating attitude in balancing the freedom of the press and reasonable restrictions replicating tenets of good governance.

\section{References}

1. Ahmed, A. M. (1999). Media Laws and Regulation in Bangladesh: Press Freedom and Its Constraints, IMK, University of Oslo: Oslo.

2. Albarran, A. B. (2010). The media and the communication industries: a $21^{\text {st }}$ century perspective. ComHumanitas: revista científica de comunicación, 59-68.

3. Anam, M. (2018, Jan 31). Commentary: 'Analogue Law' for 'Digital Bangladesh'. The Daily Star. https://www.thedailystar.net/commentary/commentary-analogue-law-digital-bangladesh-1527565. Accessed 17 December 2018.

4. Bhuian, N. M. (2016, May 3). Free Freedom to Ensure Responsible Journalism, Personal Interview with The Daily Star. https://www.thedailystar.net/law-our-rights/law-interview/press-freedom-ensureresponsible-journalism-1217593. Accessed 16 December 2018.

5. Bhuiyan, AJM. S. A. (2015, Aug 25). Social Media, Freedom of Expression and the ICT Act. The Daily Star. https://www.thedailystar.net/op-ed/politics/social-media-freedom-expression-and-the-ict-act131878. Accessed 20 December 2018.

6. Bdnews24.com. (2013, Sep 26). HC Rules Contempt of Court Law Illegal. https://bdnews24.com/bangladesh/2013/09/26/hc-rules-contempt-of-court-law-illegal. Assessed 30 December 2018.

7. Bnnrc.net. (2018, Oct 15). Cabinet Approves New Act to create Independent National Broadcasting Commission for Radio, TV and Online Mass media. https://bnnrc.net/cabinet-approves-new-act-to-createindependent-national-broadcasting-commission-for-radio-tv-and-online-mass-media/. $\quad$ Accessed 26 December 2018.

8. Cillizza, C. (2014, June 25). Americans don't trust the media. That's a bad thing. The Washington Post. https://www.washingtonpost.com/news/the-fix/wp/2014/06/25/americans-dont-trust-the-media-thats-avery-bad-thing/?noredirect=on\&utm term=.19e2c12f8532. Accessed 30 December 2018.

9. Dunham, J. (2017). Press Freedom's Dark Horizon. Freedom House Report. https://freedomhouse.org/report/freedom-press/freedom-press-2017. Accessed 16 December 2018.

10.Farhana, T. (2014, March 21). Bangladesh Media: Development and Challenges. The Diplomat. https://thediplomat.com/2014/03/bangladeshs-media-development-and-challenges/. Accessed 31 December 2018.

11.Freedom House (2018, Nov 1). Freedom on the Net - Bangladesh. Available at: https://www.refworld.org/docid/5be16b2513.html. Accessed 17 December 2018.

12.Hamid, A. (2016, Feb 6). Speech of President of the People's Republic of Bangladesh. The Daily Star. https://www.thedailystar.net/frontpage/speech-president-abdul-hamid-213421. Accessed 19 December 2018. 
Business Ethics and Leadership, Volume 3, Issue 1, 2019

ISSN (online) - 2520-6311; ISSN (print) - 2520-6761

13.Harrower, $\quad$ T. (2005). Inside Reporting, New https://mssantillanesdotcom.files.wordpress.com/2014/10/inside-reporting.pdf. 19-135. Accessed 20 December 2018.

14.Hasan, K. (2018, Jan 11). Survey: 57\% readers skeptical on media reports. The Dhaka Tribune. https://www.dhakatribune.com/bangladesh/nation/2018/01/11/readers-sceptical-media-reports. Accessed 29 December 2018.

15.Heywood, A. (2000). Key Concepts in Politics, Palgrave Macmillan, New York. 190-200.

16.Hooper, D. (1987). Official Secrets: The Use and Abuse of the Act, London, Secker \& Warburg.

17.Herbert, J. (2000). Journalism in the Digital Age: Theory and Practice for Broadcast, Print and Online Media, Oxford, Boston: Focal Press.

18.Hudock, A. (2003). Hearing the Voices of the Poor: Encouraging Good Governance and Poverty Reduction through Media Sector Support, Washington D. C.: World Learning.

19.Islam, M. (1995). Constitutional Law of Bangladesh, Bangladesh Institute of Law and International Affairs (BILIA), Dhaka, 208.

20.Itule, B., Anderson, D. A. (2007). News Writing and Reporting for Today's Media, $7^{\text {th }}$ Edition, McGraw Hill New York, USA.

21.Jahangir, M. (2015, June 16). Manik Miah: A Legendary Journalist. The Daily Star. https://www.thedailystar.net/op-ed/manik-miah-legendary-journalist-97522. Accessed 15 December 2018.

22. Kabir, N. (2003). Media Regime in Bangladesh: Rule of Obstructive Law', A Paper Presented at Odhikar's Workshop on Media, Democracy and Human Rights, Dhaka: Odhikar.

23.Kelly, M., Mazzoleni, G. and McQuail, D. (eds.), (2004). The Media in Europe: the Euromedia Handbook, London: Sage.

24.Khan, T., Kaarishma, S. E. (2014). Freedom of the Press in Bangladesh. The International Journal of Social Sciences, 25(1), 11-23.

25.Khatun, A., Abir, J. I., Rahman, M. Rahman, M. G. (2017). Press Freedom Dynamics in Bangladesh in Elsebeth Frey, Mofizur Rhaman and Hamida El Bour (eds.). Negotiating Journalism. Core Values and Cultural Diversities. Göteborg: Nordicom. http://www.nordicom.gu.se/sites/default/files/kapitelpdf/07_khatun_et_al.pdf. Accessed 25 December 2018.

26.Majumdar, A. (2007, Sep 21). Bangladesh Suspends Magazine over Controversial Character. The Reuters. https://www.reuters.com/article/us-bangladesh-cartoon/bangladesh-suspends-magazine-overcontroversial-cartoon-idUSSP17474120070921. Accessed 26 December 2018.

27.Manik, J. A. (2014, Aug 14). Censorship in True Sense. The Dhaka Tribune. Available at: https://www.dhakatribune.com/uncategorized/2014/08/14/censorship-in-the-true-sense. Accessed 20 December 2018.

28. Manuli, G. (2013, May 7). Less than 14\% of the World Lives in Countries with Free Press. Global Investigative Journalism Network. https://gijn.org/2013/05/07/less-than-14-of-the-world-lives-incountries-with-a-free-press/. Accessed 25 December 2018.

29.Marx, G. T. (2001). Censorship and Secrecy, Social and Legal Perspectives. International Encyclopedia of the Social and Behavioral Sciences. http:/web.mit.edu/gtmarx/www/cenandsec.html. Accessed 12 December 2018.

30.Milton, J. (1990). Areopagitica in Complete English Poems, Of Education, ed. Gordon Campbell, London: J.M. Dent \& Sons Ltd. First Published in 1644.

31.Rabbi, A. R. (2018, Aug 10). Number of ICT Cases on the Rise Again. The Dhaka Tribune. https:/www.dhakatribune.com/bangladesh/law-rights/2018/08/10/number-of-ict-cases-on-the-rise-again. Accessed 14 December 2018.

32.Reporters Sans Frontiers (RSF). (2018, April 26). Bangladesh has the Worst Media Freedom in South Asia. https://worldtimes24.com/bd-worst-media-freedom-sa/. Accessed 29 December 2018.

33.Singhvi, A. (2016, June 21). When Journalists are Killed, Prosecutions are Rare. The New York Times. https://www.nytimes.com/interactive/2016/06/17/world/journalists-killed-prosecutions-rare.html.

Accessed 28 December 2018.

34.White, A. (2015, Feb 19). The 5 Core Values of Journalism. YouTube. Available at: https://www.youtube.com/watch?v=uNidQHk5SZs. Accessed 28 December 2018.

35.Yew, L. K. (1971, June 9). Address of the President of Singapore to the General Assembly of the International Press Institute at Helsinki. https://www.bbc.com/news/world-asia-31582842. Accessed 31 December 2018.

36.Zamir, M. (2018, Sep 1). Using freedom of expression responsibly. The Dhaka Tribune. https://www.dhakatribune.com/opinion/op-ed/2018/09/01/using-the-freedom-of-expression-responsibly. Accessed 16 December 2018. 